\title{
$\beta$-Cell Growth and Mass Are Preserved in Long-Term Syngeneic Islet Transplantation in Streptozocin-Induced Diabetic Lewis Rats
}

\author{
Victor Nácher, Mercè Raurell, J. Francisco Merino, Olga Aranda, Joan Soler, and Eduard Montana
}

We determined $\beta$-cell replication and mass in basal and stimulated conditions in long-term transplanted islets. Three groups of streptozocin-induced diabetic Lewis rats were transplanted with 1,000 islets $(500$ islets under left and right kidney capsules). At 2 (Tx2), 5 (Tx-5), or 9 (Tx-9) months after transplantation, one of the two grafts (basal) was harvested; 14 days later, the contralateral graft (stimulated) was also harvested. Normoglycemia was achieved and maintained in all transplanted rats, although the capacity to respond to a glucose challenge deteriorated slightly 9 months after transplantation. $\beta$-cell replication remained stable in $T x-2, T x-5$, and $T x-9$ basal grafts and was similar to replication in a control group of nontransplanted rats $(0.28 \pm 0.06 \%)$; replication increased in Tx-2 $(0.90 \pm 0.23 \%, P<0.05)$ and $\mathbf{T x}-9$ $(0.72 \pm 0.09 \%, P<0.05)$ stimulated grafts. $\beta$-cell mass in basal grafts was similar to the initially transplanted mass ( $1.24 \pm 0.06 \mathrm{mg})$ and increased in stimulated grafts in Tx-2 $(1.91 \pm 0.38 \mathrm{mg}, P<0.05)$ and Tx-5 $(1.73$ $\pm 0.27 \mathrm{mg}, P=0.01$ ) groups, compared with basal grafts, and in Tx-2 and Tx-9 groups $(1.92 \pm 0.30 \mathrm{mg}, P$ $<0.05$ ), compared with initially transplanted mass. Therefore, $\beta$-cell replication and mass were preserved up to 9 months after syngeneic transplantation, and $\beta$ cells maintained the capacity to respond to increased metabolic demand, suggesting that replication is not a limiting factor in the survival of transplanted islets. Diabetes 45:1541-1546, 1996

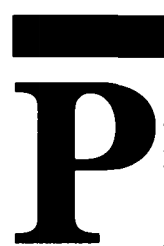

ancreas transplantation results in long-term insulin independence in a high percentage of diabetic patients (1). In contrast, normoglycemia is seldom achieved after islet allotransplantation or has short duration (2-4). The causes of the limited survival of transplanted islets, compared with whole-organ transplantation in diabetic patients, large

From the Laboratory of Diabetes and Experimental Endocrinology, Endocrine Unit, C.S.U.B.-Hospital de Bellvitge, University of Barcelona, Barcelona, Spain.

Address correspondence and reprint requests to Eduard Montana, Endocrine Unit (13-2), C.S.U.B.-Hospital Bellvitge, Feixa Llarga, s/n, 08907 L'Hospitalet de Llobregat, Barcelona, Spain.

Received for publication 11 March 1996 and accepted in revised form 27 June 1996.

ANOVA, analysis of variance; BrdU, 5-bromo-2' deoxyuridine; Tx-2, two months after transplantation; Tx-5, 5 months after transplantation; Tx-9, 9 months after transplantation. animals $(5,6)$, and rodents (7), are not well understood. Although better results have been reported with islet autotransplants (8), graft failure is also common in islet autografts (5), suggesting that nonimmunological factors play a role in the poor outcome of islet transplants.

The mass of transplanted islets plays a crucial role in the evolution of the graft. A critical islet mass, higher than predicted (9), must be transplanted to achieve normoglycemia, and late failures depend on the number of initially transplanted islets $(10-12)$. $\beta$-cell replication may be an essential determinant of the survival of transplanted islets, and a limitation in the growth capacity of transplanted islets compared with native pancreatic islets could lead to a continuous decline in $\beta$-cell mass and contribute to graft failure (13).

We have previously shown that in short-term successful islet transplants, replication of $\beta$-cells is similar to that of endogenous pancreatic $\beta$-cells, and $\beta$-cell mass is preserved (14). Furthermore, transplanted $\beta$-cells respond to changes in metabolic demand, increasing their replication and mass, and the response is similar to that of native pancreas (15). However, despite the essential role of islet mass in the outcome of the graft, $\beta$-cell replication and mass have not been determined in longterm transplanted islets. Therefore, the aim of this study was to determine the evolution of $\beta$-cell replication and mass in long-term syngeneic islet transplantation, both in basal conditions and in response to increased metabolic demand. To create a situation of increased metabolic demand, we reduced the transplanted islet mass by $50 \%$ and measured replication, size, and mass, both before and after the reduction.

\section{RESEARCH DESIGN AND METHODS}

Male Lewis rats (B \& K Universal, U.K.), aged 6-10 weeks, were used as donors and recipients of transplantation. The recipients were made diabetic by a single intraperitoneal injection of streptozocin (Streptozocin; Sigma, St. Louis, MO) $65 \mathrm{mg} / \mathrm{kg}$ body weight, freshly dissolved in citrate buffer ( $\mathrm{pH}$ 4.5). Before transplantation, diabetes was confirmed by the presence of hyperglycemia, weight loss, and polyuria. Only those rats with a blood glucose $>20 \mathrm{mmol} / \mathrm{l}$ were transplanted. Transplanted animals were bled and weighed every week for the first 2 months after transplantation and every 2 weeks thereafter. Blood glucose was determined between 9:00 and 11:00 A.M. in nonfasting conditions. Blood was obtained from the snipped tail with a heparinized microcapillary tube, and glucose was measured with a portable glucose meter (Accu-Check II, Boehringer Mannheim, Germany). Animals were kept under conventional conditions in climatized rooms with free access to tap water and standard pelleted food.

Animal groups. Three groups of streptozocin-induced diabetic rats were transplanted with 1,000 syngeneic islets, 500 under each kidney capsule, and grafts were harvested 2 months (Tx-2 group, $n=11$ ), 5 months (Tx-5 group, $n$ 
TABLE 1

Characteristics of experimental groups

\begin{tabular}{|c|c|c|c|c|c|c|c|c|c|}
\hline \multirow[b]{2}{*}{ Group } & \multirow[b]{2}{*}{$n$} & \multicolumn{2}{|c|}{ Day of transplant } & \multicolumn{2}{|c|}{2 months } & \multicolumn{2}{|c|}{5 months } & \multicolumn{2}{|c|}{9 months } \\
\hline & & $\begin{array}{c}\text { Glucose } \\
\left(\mathrm{mmol} \cdot \mathrm{l}^{-1} \cdot \mathrm{l}^{-1}\right)\end{array}$ & $\begin{array}{c}\text { Body } \\
\text { weight }(\mathrm{g})\end{array}$ & $\begin{array}{c}\text { Glucose } \\
\left(\mathrm{mmol} \cdot \mathrm{l}^{-1} \cdot \mathrm{l}^{-1}\right)\end{array}$ & $\begin{array}{c}\text { Body } \\
\text { weight ( } g)\end{array}$ & $\begin{array}{c}\text { Glucose } \\
\left(\mathrm{mmol} \cdot \mathrm{l}^{-1} \cdot \mathrm{l}^{-1}\right)\end{array}$ & $\begin{array}{c}\text { Body } \\
\text { weight }(\mathrm{g})\end{array}$ & $\begin{array}{c}\text { Glucose } \\
\left(\mathrm{mmol} \cdot \mathrm{l}^{-1} \cdot \mathrm{l}^{-1}\right)\end{array}$ & $\begin{array}{c}\text { Body } \\
\text { weight }(\mathrm{g})\end{array}$ \\
\hline $\mathrm{Tx}-2$ & 11 & $24.1 \pm 0.9$ & $147 \pm 8$ & $5.0 \pm 0.3$ & $302 \pm 13$ & - & - & - & - \\
\hline Tx-5 & 11 & $24.8 \pm 0.7$ & $142 \pm 6$ & $5.6 \pm 0.3$ & $292 \pm 15$ & $5.3 \pm 0.3$ & $378 \pm 17$ & - & - \\
\hline Tx-9 & 13 & $26.2 \pm 0.7$ & $141 \pm 6$ & $4.9 \pm 0.2$ & $273 \pm 7$ & $4.7 \pm 0.2$ & $362 \pm 11$ & $5.1 \pm 0.2$ & $404 \pm 15$ \\
\hline C-2 & 6 & - & - & $5.1 \pm 0.2$ & $350 \pm 14$ & - & - & - & - \\
\hline C-9 & 6 & - & - & - & - & - & - & $3.9 \pm 0.1$ & $461 \pm 36$ \\
\hline Control* & 6 & $4.0 \pm 0.2$ & $201 \pm 9$ & $4.3 \pm 0.2$ & $330 \pm 29$ & $4.2 \pm 0.1$ & $409 \pm 26$ & $4.2 \pm 0.2$ & $479 \pm 27$ \\
\hline
\end{tabular}

Data are means $\pm \mathrm{SE}$. In the control group, day of transplant columns show blood glucose values and body weights of normal non-streptozocin-injected animals of similar age to the transplanted rats.

= 11), or 9 months (Tx-9 group, $n=13$ ) after transplantation (Table 1). In each transplanted group, five rats had both grafts removed simultaneously to determine basal $\beta$-cell replication. The remaining animals had one graft (basal) initially harvested and the contralateral graft (stimulated) harvested 14 days later. Because harvesting of basal grafts reduced the transplanted $\beta$-cell mass by $50 \%$, the stimulated graft had to meet an increased metabolic demand to maintain normoglycemia. Blood glucose and body weight were measured daily after basal graft harvesting. Immediately after the harvesting of the grafts, animals were killed and the pancreas excised to determine insulin content. Rats were randomly distributed among the three transplant groups; basal grafts were randomly harvested from the left and right kidney capsules to prevent any interference due to transplantation technique. One rat developed a kidney neoplasia 8 months after transplantation, and one rat in the Tx-9 group died for technical reasons after basal graft harvesting; both were excluded.

Three control groups of normal nontransplanted rats were studied (Table 1). Rats in the control group $(n=6)$ had blood glucose and body weight determined monthly and underwent an intraperitoneal glucose tolerance test at 4,7 , and 11 months of age. The other two groups had their pancreases excised when they were 4 months old (C-2 group) and 11 months old (C-9 group), the same age as the Tx-2 and Tx-9 groups, respectively, to determine $\beta$-cell replication in normal pancreas. The insulin content in normal pancreas was determined in five additional rats. Finally, the $\beta$-cell mass of eight groups of 500 isolated islets was measured to determine the initially transplanted $\beta$-cell mass.

Isolation and transplantation. Islets were isolated, as previously described (14). Briefly, after pancreas digestion with collagenase (Collagenase P; Boehringer Mannheim) in a stationary bath at $37^{\circ} \mathrm{C}$, islets were separated on a density gradient (Hystopaque-1077; Sigma). Isolated islets were hand-picked under a stereomicroscope two or three times until a population of pure islets was obtained. Only islets $>75$ and $<250 \mu \mathrm{m}$ in diameter were collected and carefully counted into two groups of 500 islets that were transplanted under the left and right kidney capsules on the day of the isolation. The two groups of islets were placed into 200- $\mu$ l pipette tips, allowed to sediment, and then gently transferred to a polyethylene tubing PE-50 (Becton Dickinson, Sparks, MD) with the help of a 1-ml Hamilton syringe (Hamilton, Reno, NE). The tubing was folded and centrifuged for $1 \mathrm{~min}$ at $400 \mathrm{~g}$ to pellet the islets; after centrifugation the pipette tip was connected again to the Hamilton syringe. With the rats under light ether anesthesia, the kidney was exposed through a lumbar incision. A capsulotomy was performed in the lower pole of the kidney and the tip of the tubing advanced under the capsule to the upper pole where islets were carefully injected. The lumbar incision was sutured and the same process was performed to inject the other 500 -islet pellet under the kidney capsule of the contralateral kidney

Graft and pancreas removal in transplanted groups. To determine $\beta$-cell replication, rats were injected with the thymidine analog 5-bromo2 'deoxyuridine (BrdU) (Sigma), $100 \mathrm{mg} / \mathrm{kg}$ body wt i.p., and $6 \mathrm{~h}$ later, the grafts were harvested and the animals were killed. In each transplanted group, five animals were injected with $\mathrm{BrdU}$ and had both grafts removed simultaneously to determine basal $\beta$-cell replication. In the remaining animals, BrdU was injected only when the stimulated graft was harvested to determine stimulated $\beta$-cell replication. In this way, we excluded any possible interference from previously incorporated $\mathrm{BrdU}$ in the measurement of stimulated $\beta$-cell replication and any possible toxic effect of the drug (16). With the rat under light ether anesthesia, the kidney was exposed and the graft identified as a white patch. The kidney capsule surrounding the graft was incised and removed with the graft. Usually, all the graft was removed with the capsule; in the cases where the grafted islets were infiltrating the kidney cortex, a second piece of tissue was also taken to ensure that the entire graft was taken. After basal graft harvesting, the kidney bearing the graft was also excised to further ensure that no islet tissue was left. After removal, the graft was fixed in Bouin's solution and processed for paraffin embedding. The weight of the graft was determined on a Mettler balance type A240 reading to $0.01 \mathrm{mg}$ (Mettler Instruments, NJ), as described earlier (14). After harvesting of both grafts, rats were killed and the pancreas was immediately excised and stored at $-20^{\circ} \mathrm{C}$ in acid ethanol until processed for insulin content determination. The pancreatic insulin content was determined to ensure that normoglycemia had been maintained by transplanted islets.

Pancreas removal in nontransplanted groups. Normal C-2 and C-9 group animals were injected with BrdU $6 \mathrm{~h}$ before pancreas excision, as described for transplanted rats. A midlaparotomy was performed and the pancreas was exposed, the animal was killed, and the pancreas was dissected from surrounding tissues, excised, blotted, weighed, and fixed in Bouin's solution. Subsequently, the pancreatic tissue was embedded in paraffin. In the five normal rats used to determine insulin content, the pancreas was excised, blotted, and immediately stored at $-20^{\circ} \mathrm{C}$ in acid ethanol until processed for insulin content determination.

Immunocytochemistry. Two-micrometer sections of graft and pancreas were double-stained for BrdU and for the endocrine non- $\beta$-cells of the islets with immunoperoxidase. Immunostaining for BrdU used a Cell Proliferation Kit (Amersham International, Amersham, U.K.). Staining for the endocrine non- $\beta$-cells used a cocktail of antibodies (Dako, Carpinteria, CA): rabbit anti-porcine glucagon (final dilution 1:1,000), rabbit anti-human somatostatin (final dilution 1:1,000), and rabbit anti-human pancreatic polypeptide (final dilution 1:500). A swine anti-rabbit IgG was used as a secondary antibody. The sections were stained with 3,3'-diaminobenzimide tetrahydrochloride (Sigma) and hydrogen peroxide (Merck, Darmstadt, Germany). $\beta$-cell replication, individual $\beta$-cell area, and $\beta$-cell mass. Methods used for measurement of $\beta$-cell replication, area, and mass have been described in detail (14). For $\beta$-cell replication, $\beta$-cells and BrdU-positive $\beta$-cells were counted using an Olympus BH-2 microscope connected to a video camera with a color monitor. Results were expressed as the percentage of BrdU-positive $\beta$-cells. At least 1,500 cells were counted per graft or pancreas.

The mean cross-sectional area of individual $\beta$-cells, a measure of $\beta$-cell size, was determined on immunoperoxidase-stained sections of grafts and isolated islets. For both grafts and isolated islets, the $\beta$-cell nuclei on a random field were counted and the area of the $\beta$-cell tissue in that field measured with an electronic planimetry program (Sigma Scan 3.9; Jandel, Erkrath, Germany). The $\beta$-cell area was divided by the number of $\beta$-cell nuclei to calculate the area of the individual $\beta$-cells. As pointed out previously (14), the actual number of $\beta$-cells was higher than the number counted, since not all $\beta$-cells were sectioned across their nuclei and, therefore, the size of the $\beta$-cells was overestimated.

$\beta$-cell mass was measured by point-counting morphometry on immunoperoxidase-stained sections of graft and endogenous pancreas. Each section was covered systematically using a 48-point grid to obtain the number of intercepts over $\beta$-cells, over endocrine non- $\beta$-cells, and over other tissue. The $\beta$-cell relative volume was calculated by dividing the intercepts over $\beta$-cells by intercepts over total tissue; then the $\beta$-cell mass was estimated by multiplying $\beta$-cell relative volume by graft weight. Endocrine non- $\beta$-cell mass and pancreatic exocrine mass were obtained in the same way. The $\beta$-cell mass of the islets at the time of the transplantation was determined in eight groups of 500 islets isolated on different days. $\beta$-cell 

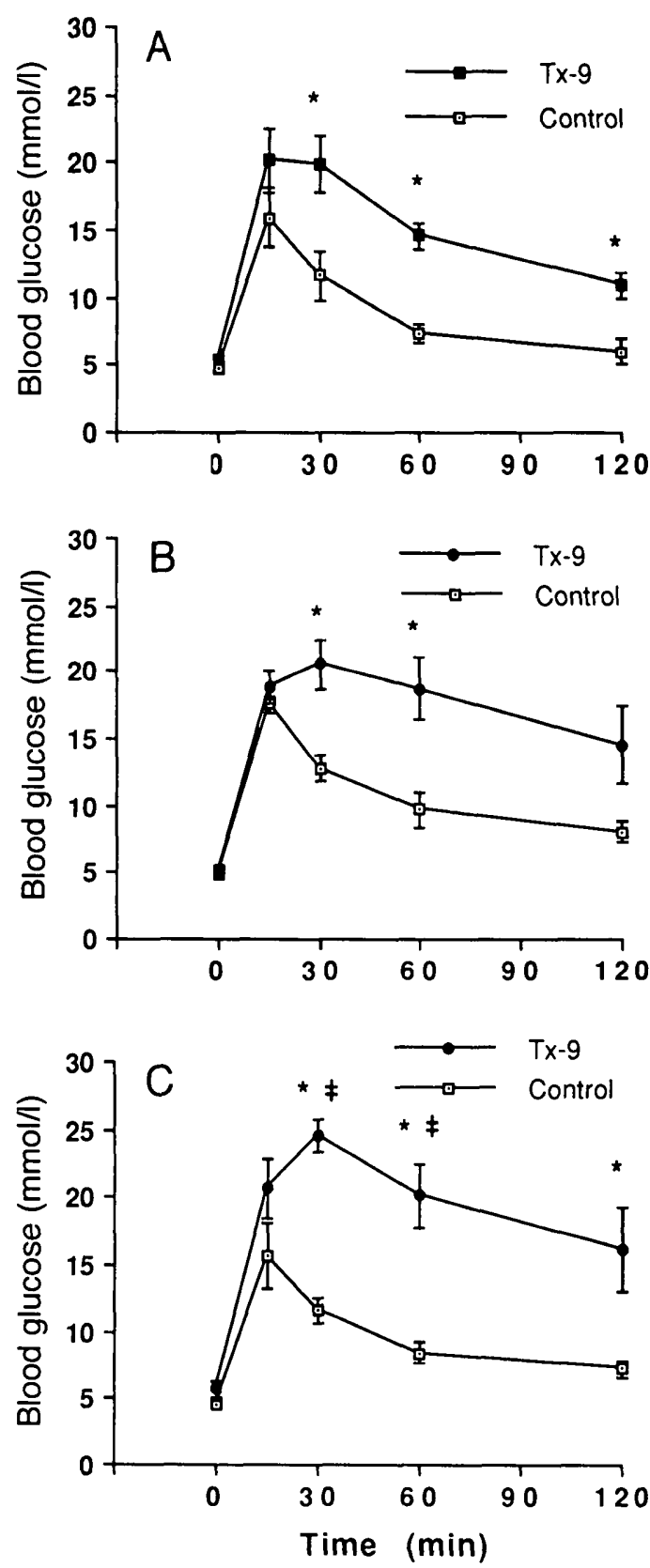

FIG. 1. Intraperitoneal glucose tolerance test in six transplanted (Tx-9 group) and four normal rats (control group) 2 months after transplantation $(A), 5$ months after transplantation $(B)$, or 9 months after transplantation $(C)$. Control animals were 4,7 , and 11 months old, respectively. Values are means \pm SE. ${ }^{*} P<0.05$ between transplanted and control groups; $¥ P<0.05$ between month 2 and month 9 transplanted rats.

mass was obtained by multiplying the weight of the islets by the percentage of $\beta$-cell volume, as derived from our data (91.3\%).

Intraperitoneal glucose tolerance test. The intraperitoneal glucose tol erance test was performed in six rats of the Tx-9 group 2, 5, and 9 months after transplantation and in four age-matched rats of the control group when they were 4, 7, and 11 months old. Between 11:00 A.M. and noon, after a 2-h fast, nonanesthetized rats were injected with a $30 \%$ glucose solution (Sigma), $2 \mathrm{~g} \cdot \mathrm{kg}^{-1} \cdot$ body $\mathrm{wt}^{-1}$ i.p. Blood glucose was determined at the time of injection and $15,30,60$, and 120 min later.

Insulin content. Pancreatic insulin content was determined in five norma rats and in all transplanted rats after the harvesting of both grafts to ensure that normoglycemia had been maintained by transplanted islets. After excision, the pancreases were stored in acid ethanol at $-20^{\circ} \mathrm{C}$ until homogenized with an Ultra Turrax T-25 homogenizer (Janke \& Kendel GMBH \& Co. KG, Ika-

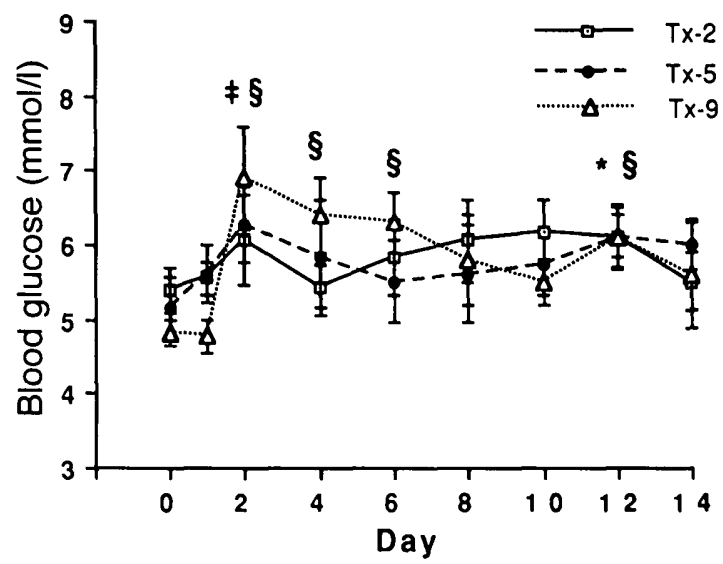

FIG. 2. Evolution of fed blood glucose after basal graft harvesting in transplanted groups. Groups are described in Table 1. Basal graft was harvested on day 0 , and stimulated graft was harvested 14 days later. Values are means \pm SE. ${ }^{*} P<0.05$ vs. day 0 in the Tx-2 group; $\ddagger P<0.05$ vs. day 0 in the Tx-5 group; $\S P<0.05$ vs. day 0 in the Tx-9 group.

Laborthecnik, Staufen, Germany). After homogenization, the samples were extracted overnight at $4^{\circ} \mathrm{C}$. On the following day, they were centrifuged at $2,400 \mathrm{rpm}$ for $10 \mathrm{~min}$ and the supernatant was stored at $-20^{\circ} \mathrm{C}$. The pellet was again homogenized in acid ethanol and insulin extracted overnight. After centrifugation, this second supernatant was added to the first extraction sample. Insulin was measured by radioimmunoassay using a rat insulin standard (Novo Nordisk, Copenhagen, Denmark) and polyethyleneglycol separation. Statistical analysis. Results were expressed as means \pm SE. For comparisons between basal and stimulated grafts, the paired or unpaired Student's $t$ test was used, as appropriate, and for multiple comparisons between groups, the one-way analysis of variance (ANOVA) was used. A $P$ value of $<0.05$ was considered significant.

\section{RESULTS}

Metabolic evolution after transplantation. All groups were comparable in age and body weight when injected with streptozocin at the start of experiments (data not shown). At the time of transplantation, diabetic groups had similar blood glucose and body weight. Normoglycemia was restored in all animals 1 month after transplantation and was maintained throughout followup (Table 1). Insulin content was very low in pancreases of transplanted rats compared with normal rats $(70.9 \pm$ $8.6 \mu \mathrm{g} /$ pancreas) and did not change with time (Tx-2 group: $4.81 \pm 1.2 \mu \mathrm{g} /$ pancreas; $\mathrm{Tx}-5$ group: $3.95 \pm 1.2$ $\mu \mathrm{g} /$ pancreas; Tx-9 group: $3.22 \pm 0.6 \mu \mathrm{g} /$ pancreas).

Transplanted rats showed higher glucose values than control rats 30,60 , and 120 min after intraperitoneal glucose injection at any time point after transplantation (Fig. 1). Aging did not modify glucose tolerance in the control group; in contrast, glucose tolerance deteriorated in older transplanted rats, which, 9 months after transplantation, exhibited higher glucose values 30 min ( 2 months: $19.9 \pm$ $2.1 \mathrm{mmol} / \mathrm{1}$; 9 months: $24.7 \pm 1.3 \mathrm{mmol} / 1, P<0.05)$ and 60 min (2 months: $14.6 \pm 0.9 \mathrm{mmol} / \mathrm{l} ; 9$ months: $20.2 \pm 2.3$ $\mathrm{mmol} / \mathrm{l}, P<0.05)$ after glucose injection.

Blood glucose evolution after basal graft extraction. Harvesting of basal grafts resulted in mild and transient hyperglycemia, but when stimulated grafts were harvested 14 days later, all groups were normoglycemic (Fig. 2). However, the evolution of blood glucose in the days between basal and stimulated graft harvesting was different in the three transplanted groups. In Tx-2 group, 


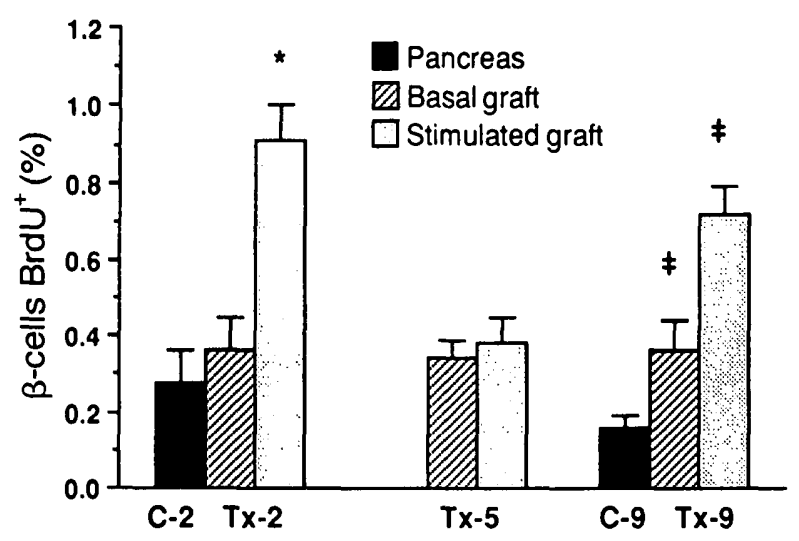

FIG. 3. $\beta$-cell replication in normal pancreas and in transplanted islets. Replication is expressed as percentage of BrdU-positive $\beta$-cells. Groups on the $\boldsymbol{x}$-axis correspond to those described in Table 1 and in METHods. Values are means \pm SE. ${ }^{*} P<0.05$ between stimulated Tx-2 grafts and basal Tx-2 grafts and C-2 group (oneway ANOVA, $P<0.01$ ). $\ddagger P<0.01$ between stimulated Tx-9 grafts and basal Tx-9 grafts and C-9 group and between basal Tx-9 grafts and $\mathbf{C - 9}$ group (one-way ANOVA, $P<0.001$ ).

hyperglycemia was detected on day 12 after basal graft harvesting, and there was also a tendency toward hyperglycemia on days $9(P=0.056), 10(P=0.067)$, and $11(P$ $=0.055$ ), compared with day 0 . The Tx-9 group was hyperglycemic throughout the first 6 days after basal graft harvesting and again on day 12 . In contrast, Tx-5 rats exhibited a better metabolic profile, since they were mildly hyperglycemic only on day 2 after basal graft harvesting and remained strictly normoglycemic afterwards. $\boldsymbol{\beta}$-cell replication. In basal grafts, replication of $\beta$-cells was similar in all transplanted groups, remained stable throughout the follow-up, and was similar to replication in $\beta$-cells in the normal pancreases of the C-2 group $(0.28$ $\pm 0.06 \%$ ) (Fig. 3). However, basal $\beta$-cell replication was increased in the $\mathrm{Tx}-9$ group $(0.36 \pm 0.08 \%)$, compared with the normal pancreases of the age-matched C-9 group $(0.16 \pm 0.03 \%, P<0.01)$. $\beta$-cell replication increased in the Tx-2 group-stimulated grafts, compared with basal grafts $(0.90 \pm 0.23$ vs. $0.32 \pm 0.09 \%, P<0.05)$ and with normal pancreas of the age-matched C-2 group $(P<0.01)$. A similar increase was found in Tx-9 group-stimulated grafts $(0.72 \pm 0.09 \%)$, compared with basal grafts and with the age-matched C-9 group $(P<$ $0.001)$. No differences in $\beta$-cell replication were detected between the C-2 and C- 9 groups, between $\mathrm{Tx}-5$ group basal and stimulated grafts, or between the Tx-2 group and Tx-9 group-stimulated grafts.

$\boldsymbol{\beta}$-cell area. The individual cross-sectional area of $\beta$ cells in isolated islets was $210 \pm 6 \mu^{2}$. $\beta$-cell size in basal grafts was similar in transplanted groups (Tx-2: $256 \pm 15$

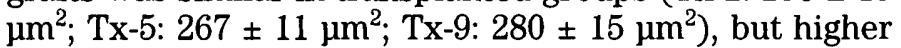
than in isolated islets $(P=0.008)$ (Fig. 4). $\beta$-cell size increased in stimulated grafts in the Tx-9 group (328 \pm 17 $\mu^{2}, P<0.05$ ), compared with basal grafts, but not in the $\mathrm{Tx}-2\left(287 \pm 13{\left.\mu \mathrm{m}^{2}\right)}^{2}\right.$ and Tx-5 $\left(287 \pm 12 \mu \mathrm{m}^{2}\right)$ groups.

$\boldsymbol{\beta}$-cell mass. $\beta$-cell mass in basal grafts in the Tx- $2(0.90$ $\pm 0.16 \mathrm{mg}), \mathrm{Tx}-5(0.99 \pm 0.24 \mathrm{mg})$, and $\mathrm{Tx}-9(1.56 \pm 0.23$ $\mathrm{mg}$ groups was similar to the initially transplanted $\beta$ cell mass in 500 isolated islets (1.24 $\pm 0.06 \mathrm{mg}$ ) (Fig. 5).

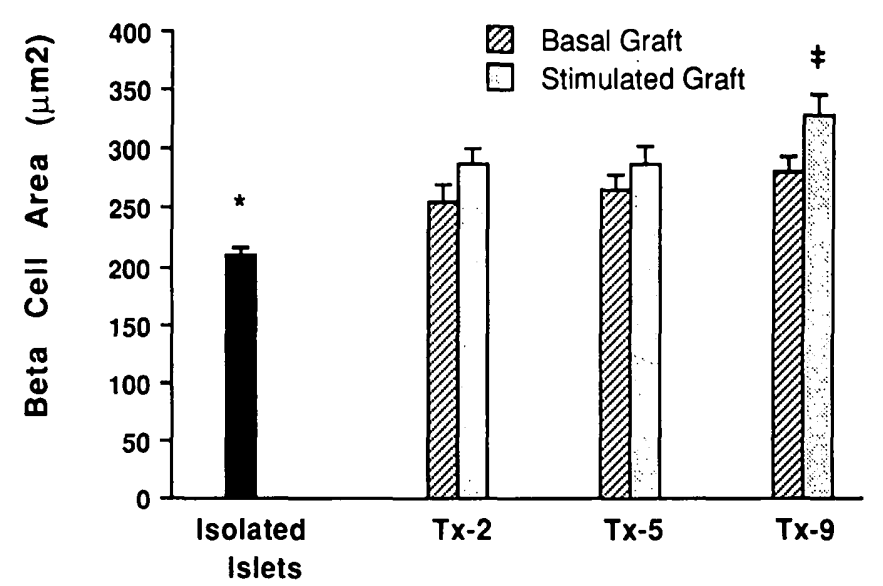

FIG. 4. Area of individual $\beta$-cells from isolated and transplanted islets. Names on the $x$-axis correspond to groups shown in Table 1. Isolated islets show $\beta$-cell area on transplantation day. Values are means \pm SE. $* P<0.01$ between isolated islets and all other groups. $\ddagger P<0.05$ between basal and stimulated grafts.

$\beta$-cell mass was increased in stimulated grafts in the Tx$2(1.91 \pm 0.38 \mathrm{mg}, P<0.05)$ and Tx-5 $(1.73 \pm 0.27 \mathrm{mg}, P=$ $0.01)$ groups, compared with basal grafts, and in the Tx2 and Tx-9 $(1.92 \pm 0.30 \mathrm{mg}, P<0.05)$ groups, compared with the initially transplanted mass. However, in the Tx9 group, $\beta$-cell mass in the stimulated grafts was not higher than that in basal grafts. It must be noticed, however, that the $\beta$-cell mass in basal grafts in the Tx-9 group was already increased $(P<0.05)$, compared with basal grafts in the Tx-2 group.

No changes in endocrine non- $\beta$-cell mass were found between basal and stimulated groups, indicating the specificity of $\beta$-cell response to changes in metabolic demand.

\section{DISCUSSION}

We have determined the evolution of metabolic control and $\beta$-cell replication, size, and mass 2,5 , and 9 months after syngeneic islet transplantation. Transplanted $\beta$-cells were studied in basal and stimulated conditions after a $50 \%$ reduction of transplanted islet mass. Normoglycemia was achieved and maintained throughout the follow-up in all transplanted rats, although the capacity to respond to a glucose challenge deteriorated slightly 9 months after transplantation. $\beta$-cell replication remained stable in basal grafts and increased in stimulated grafts, indicating preserved $\beta$-cell replicative capacity. $\beta$-cell mass in basal grafts was similar to the initially transplanted mass and increased in stimulated grafts, compared with basal grafts or with the initially transplanted mass. Nine months after transplantation, $\beta$-cell mass did not increase significantly in stimulated grafts compared with basal grafts, despite increased $\beta$-cell replication and size, suggesting that the capacity of long-term transplanted $\beta$-cells to survive severe increments in metabolic demand may be limited.

Rats were transplanted with 1,000 islets because this is the minimal $\beta$-cell mass that consistently achieves normoglycemia after syngeneic transplantation into streptozocin-induced diabetic rats (17-19). This borderline $\beta$-cell mass was transplanted into two grafts of 500 islets to ensure that harvesting of one graft would significantly 


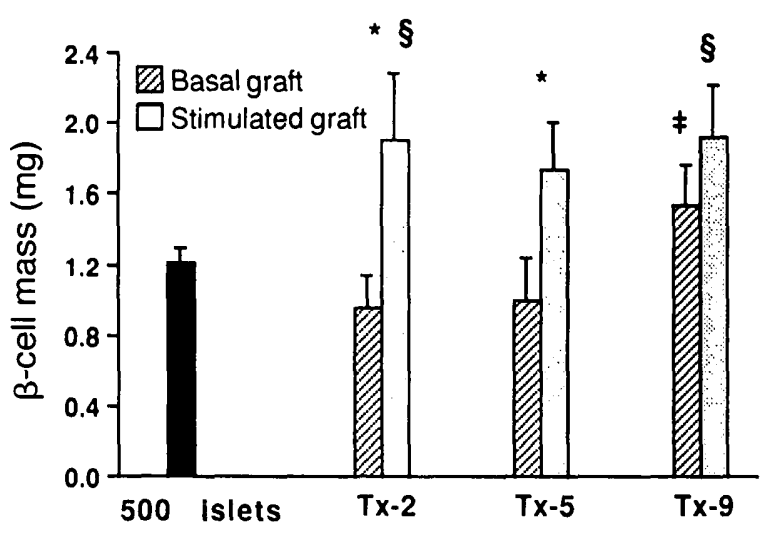

FIG. 5. $\beta$-cell mass initially transplanted and in basal and stimulated grafts. Names on the $\boldsymbol{x}$-axis correspond to groups shown in Table 1. The bar representing 500 islets shows the initially transplanted $\beta$-cell mass in 500 islets. Values are means \pm SE. $* P<0.05$ between basal and stimulated grafts. $\ddagger P<0.05$ between basal Tx-9 group grafts and basal Tx-2 group grafts. $\$ P<0.05$ between Tx-2 and Tx-9 stimulated grafts and 500 isolated islets.

challenge the $\beta$-cells of the remaining graft; the model proved to be very useful to determine the adaptation of transplanted $\beta$-cells to changes in metabolic demand. Moreover, transplantation of a minimal $\beta$-cell mass increased the possibilities to detect any worsening of glucose control, since late failures of transplanted islets have been related to the amount of initially transplanted mass (10-12). The results showed that the transplanted islet mass restored normoglycemia and maintained it throughout the 9-month follow-up, although transplanted rats were persistently less efficient than normal rats to control an acute intraperitoneal glucose challenge. In response to increased metabolic demand, Tx-9 rats had prolonged hyperglycemia after basal graft harvesting, and glucose control after intraperitoneal glucose injection deteriorated 9 months after transplantation. In contrast, no changes in glucose tolerance were found in old control rats, indicating that deterioration was specific for transplanted islets. A shorter follow-up after transplantation (18) or the transplantation of a higher $\beta$-cell mass (20) could have precluded the finding of such deterioration in glucose metabolism and may explain some of the discrepancies about $\beta$-cell function in transplanted islets $(6-8)$. Therefore, transplantation of a borderline $\beta$-cell mass maintained fasting and fed normoglycemia for extended periods of time, although the capacity to meet an increased metabolic demand deteriorated slightly in long-term transplanted islets.

$\beta$-cell replication was similar in basal grafts of the $\mathrm{Tx}$ 2 , Tx-5, and Tx-9 groups and increased in stimulated grafts in Tx-2 and Tx-9 rats, indicating preserved $\beta$-cell replication in long-term transplanted islets. On the other hand, $\beta$-cell replication was not increased in the Tx-5 group when stimulated grafts were harvested. Glucose is a well-known stimulus for $\beta$-cell replication, both in vitro $(21,22)$ and in vivo (23), and hyperglycemia, present in the Tx-2 and Tx-9 groups just before harvesting the stimulated grafts, probably increased $\beta$-cell replication in these groups. In contrast, in the Tx-5 group, hyperglycemia was detected only in the first 2 days after basal graft harvesting and rats remained normoglycemic thereafter. In parallel with the evolution of blood glucose in the Tx- 5 group, $\beta$-cell replication probably increased the first days after basal graft harvesting, as suggested by the increased $\beta$-cell mass in stimulated grafts, and then returned to the basal level. The better evolution of blood glucose after basal graft harvesting in the Tx-5 group compared with the Tx-2 group may be related to the process of engraftment, which needs several months to be completed. Initial reinnervation of islets transplanted under the kidney capsule has been detected 2 months after transplantation, but reinnervation is not clearly established until 3-4 months later, and some changes take place even later (24). In association with the reinnervation of transplanted islets, coordinate pulsatile insulin delivery is established 6 months after transplantation and is accompanied with increased total insulin secretion (25). Therefore, better islet engraftment in the Tx-5 group may have resulted in shorter hyperglycemia after basal graft harvesting and, in more transient increment, in $\beta$-cell replication. Dunger et al. (26) reported increased replication in pancreatic islets transplanted into the kidney capsule when the non-islet-bearing kidney was removed, although the results were not confirmed in a recent study (27). The absence of increased replication in the $\mathrm{Tx}-5$ group indicates that increased $\beta$-cell replication did not result from local nonspecific growth stimulation secondary to nephrectomy.

$\beta$-cell replication in the Tx-9 group basal grafts was higher than in the normal age-matched C-9 group. The increased replication suggests that $\beta$-cells were already stimulated in basal grafts, a suggestion further supported by their increased $\beta$-cell mass. Higher metabolic demand in older Tx-9 rats due to insulin resistance may have resulted in increased $\beta$-cell replication and mass in basal grafts. This increased $\beta$-cell replication in basal grafts and the further increment in stimulated grafts indicate that $\beta$-cell replicative capacity was preserved in longterm transplanted islets.

In the normal adult pancreas, $\beta$-cell regeneration takes place through the replication of $\beta$-cells, but in particular conditions, a second pathway of regeneration occurs and new $\beta$-cells differentiate from precursor cells of the ductal epithelium (28-31). However, transplanted islets are deprived of ductular structures and cannot use this pathway to increase their $\beta$-cell mass. Furthermore, it has been suggested that the absence of ductal precursors may prevent the renewal of the replicative pool of transplanted $\beta$-cells (13). In situations of increased $\beta$-cell destruction, such as rejection episodes, the absence of ductular precursor cells could limit the capacity of grafted islets to regenerate and replace dying $\beta$-cells and could contribute to the limited survival of transplanted islets, compared with whole-organ transplants $(1,8)$. Our results, however, show that $\beta$-cell replication was preserved in long-term transplanted islets and suggest that lack of ductular structures was not a limiting factor in the regeneration of transplanted $\beta$-cells, even when $\beta$-cell mass was severely reduced.

$\beta$-cell mass results from a dynamic balance between cell proliferation, cell size, and cell death (32). In basal grafts, $\beta$-cell replication, size, and mass remained stable 
in the first 5 months after transplantation, indicating that in the absence of immune rejection, transplanted $\beta$-cells maintained a balance between the rate of appearance of new $\beta$-cells and the rate of $\beta$-cell loss. Furthermore, in response to increased metabolic demand, transplanted islets increased $\beta$-cell replication and mass and maintained normoglycemia. In the Tx-9 group, $\beta$-cell replication and mass were already increased in basal grafts, showing that the capacity to respond to moderate increases in demand was preserved. However, when metabolic demand was further increased after basal graft harvesting, $\beta$-cell replication and size increased in stimulated grafts, but $\beta$-cell mass did not change significantly, suggesting that $\beta$-cell death could be increased. The causes of the limited capacity of the Tx-9 group $\beta$-cells to survive this additional and severe increment in metabolic demand are not known but could play a role in the poor long-term outcome of islet transplantation.

In summary, we have shown that long-term transplanted islets have a preserved $\beta$-cell replication and mass and a remarkable capacity to respond to increased metabolic demand, even when only a borderline $\beta$-cell mass is transplanted. In basal conditions, $\beta$-cell replication was sufficient to compensate normal $\beta$-cell death and to maintain $\beta$-cell mass; in stimulated conditions, $\beta$-cell replication and mass increased, and normoglycemia was maintained, although in extreme conditions, a limited capacity to increase $\beta$-cell mass was found. The results are very encouraging for the future of transplanted islets, since they indicate that the long-term survival of islets should not be hampered by limitations in the replicative capacity of transplanted $\beta$-cells.

\section{ACKNOWLEDGMENTS}

This work was supported by grant FIS-93/329 from the Ministry of Health of Spain. V.N. and M.R. were the recipients of grants from Fundació August Pi I Sunyer. J.F.M. was the recipient of a grant from the Commission for Universities and Research of the Government of Catalonia.

We thank R. Font Altaba for financial support.

\section{REFERENCES}

1. Morel P, Goetz FC, Moudri-Munnis K, Freier E, Sutherland DER: Longterm glucose control in patients with pancreatic transplants. Ann Int Med 115:694-699, 1991

2. Scharp DW, Lacy PE, Santiago JV, McCullough CS, Weida LG, Boyle PJ Falqui L, Marchetti P, Ricordi C, Gingerich RL, Jaffe AS, Cryer PE, Hanto DW, Anderson C, Flye MW: Results of our first nine intraportal islet allografts in type 1, insulin-dependent diabetic patients. Transplantation 51:76-86, 1991

3. Warnock GL, Kneteman NM, Ryan E, Seelis REA, Rabinovitch A, Rajotte RV: Normoglycemia after transplantation of freshly isolated and cryopreserved pancreatic islets in type 1 (insulin-dependent) diabetes mellitus. Diabetologia 34:54-58, 1991

4. Hering BJ, Geier C, Schultz AO, Bretzel RG, Federlin K: International Islet Transplant Registry. Justus-Liebig-University of Giessen, Germany. 5:10-27, 1995

5. Alejandro R, Cutfield RG, Shienvold FL, Polonsky KS, Olson L, Dillberg J, Miller J, Mintz DH: Natural history of intrahepatic canine islet cells autografts. J Clin Invest 78:1339-1348, 1986

6. Sutton R, Gray DWR, McShane P, Peters M, Morris PJ: The metabolic efficiency and long-term fate of intraporta islet grafts in the cynomolgus monkey. Transplant Proc 19:3575-3576, 1987

7. Orloff MJ, Macedo A, Greenleaf GE, Girard B: Comparison of the metabolic control of diabetes achieved by whole pancreas transplantation and pancreatic islet transplantation in rats. Transplantation 45:307-312,
1988

8. Pyzdrowski KL, Kendall DM, Halter JB, Nakhler RE, Sutherland DER, Robertson RP: Preserved insulin secretion and insulin independence in recipients of islets autografts. $N$ Engl $J$ Med 327:220-226, 1992

9. Weir GC, Bonner-Weir S, Leahy JL: Islet mass and function in diabetes and transplantation. Diabetes 39:401-405, 1990

10. Warnock GL, Rajotte RV: Critical mass of purified islets that induce normoglycemia after implantation into dogs. Diabetes 37:467-470, 1988

11. Warnock GL, Dabbs KD, Evans MG, Gattral MS, Kneteman NM, Rajotte RV: Critical mass of islets that function after implantation in a large mammalian. Horm Metab Res (Suppl. 25):156-161, 1990

12. Kaufman DB, Morel P, Field MJ, Munn SR, Sutherland DER: Importance of implantation site and number of islets transplanted on functional outcome following autotransplantation in a canine model. Horm Metab Res (Suppl. 25):162, 1990

13. Bonner Weir S: Two pathways of $\beta$-cell growth in the regenerating rat pancreas: implications for islet transplantation. Diabetes Nutr Metab 5 (Suppl. 1):1-3, 1992

14. Montana E, Bonner-Weir S, Weir GC: Beta cell mass and growth after syngeneic islet cell transplantation in normal and streptozocin diabetic C57BL/6 mice. J Clin Invest 91:780-787, 1993

15. Montana E, Bonner-Weir S, Weir GC: Transplanted $\beta$-cell response to increased metabolic demand: changes in $\beta$-cell replication and mass. $J$ Clin Invest 93:1577-1582, 1994

16. Morstin G, Hsu SM, Kinsella T, Gratzner H, Russo A, Mitchell JB: Bromodeoxyuridine in tumors and chromosomes detected with a monoclonal antibody. $J$ Clin Invest 72:1844-1850, 1983

17. Bell RC, Khurana M, Ryan EA, Finegood DT: Gender differences in the metabolic response to graded numbers of transplanted islets of Langerhans. Endocrinology 135:2681-2687, 1994

18. Keymeulen B, Teng H, Vetri M, Gorus F, Pipeleers DG: Effect of donor islet mass on metabolic normalization in streptozotocin-diabetic rats. Diabetologia 35:719-724, 1992

19. Tobin BW, Lewis JT, Chen DZX, Finegood DT: Insulin secretory function in relation to transplanted islet mass in STZ-induced diabetic rats. Diabetes 42:98-105, 1993

20. Leow CK, Gray DWR, Morris PJ: The long-term metabolic function of intraportal and renal subcapsular islet isografts and the effect on glomerular basement membrane thickness in rats. Diabetologia 38:1014-1024, 1995

21. Swenne I: Effects of aging on the regenerative capacity of pancreatic $\beta$ cell of the rat. Diabetes $32: 14-19,1983$

22. Swenne I: The role of glucose in the in vitro regulation of cell cycle kinetics and proliferation of fetal pancreatic $\beta$-cells. Diabetes 31:754-760, 1982

23. Bonner-Weir S, Deery D, Leahy JL, Weir GC: Compensatory growth of pancreatic $\beta$-cells in adult rats after short term glucose infusion. Diabetes $38: 49-53,1989$

24. Korsgren O, Andersson A, Jansson L, Sundler F: Reinnervation of syngeneic mouse pancreatic islets transplanted into renal subcapsular space. Diabetes 41:130-135, 1992

25. Porksen N, Munn S, Ferguson D, O'Brien T, Veldhuis J, Butler P: Coordinate pulsatile insulin secretion by chronic intraportally transplanted islets in the isolated perfused rat liver. $J$ Clin Invest 94:219-227, 1994

26. Dunger A, Korsgren O, Andersson A: DNA replication in mouse pancreatic islets transplanted subcapsularly into the kidney or intraportally into the liver: influence of unilateral nephrectomy of partial hepatectomy. Transplantation 49:686-689, 1990

27. Jyuhn-Huarng J, Bonner-Weir S, Ying-Jian W, Weir GC: Beneficial influence of glycemic control upon the growth and function of transplanted islets. Diabetes 43:1334-1339, 1994

28. Bonner Weir S, Baxter LA, Schuppin GT, Smith FE: A second pathway for regeneration of adult exocrine and endocrine pancreas: a possible recapitulation of embryonic development. Diabetes 42:1715-1720, 1993

29. Rosenberg L, Brown RA, Duguid WP: A new model for the development of duct epithelial hyperplasia and the initiation of nesidioblastosis. $J$ Surg Res 35:63-72, 1983

30. Weaver CV, Sorenson RL, Kaung HC: Immunocytochemical localization of insulin-immunoreactive cells in the ducts of rats treated with trypsin inhibitor. Diabetologia 28:781-785, 1985

31. Gu D, Sarvetnick N: Epithelial cell proliferation and islet neogenesis in IFN-gamma transgenic mice. Development 118:33-46, 1993

32. Finegood DT, Scaglia L, Bonner-Weir S: Dynamics of $\beta$-cell mass in the growing rat pancreas: estimation with a simple mathematical model. Diabetes 44:249-256, 1995 